\title{
Bare det beste er godt nok
}

Da jeg begynte å studere medisin for snart 25 år siden, ble vi tidlig innprentet at vi måtte lære å sette grenser for oss selv. Finne ut når noe var godt nok. Vi kunne ikke gjøre alt for alle pasienter. Hvis vi ikke lærte oss begrensningens kunst, ville det gå oss ille. Vi kom til å bli utslitt og utbrent. Alle skjønte at det var lurt med grenser.

Rådet var sikkert gitt $\mathrm{i}$ beste mening. Blant ferske medisinstudenter kan det til og med være grunn til å snakke om det. Den tradisjonelle utvelgelsen til doktorskolen ut fra kun én variabel - høye karakterer fra videregående skole - selekterer mennesker som ikke har nøyd seg med det gjennomsnittlige. Vi er rekruttert etter evnen til perfeksjon. Karakterkravet har gitt næring til overdrivelser. Det er ikke forenlig med å gjøre ting «godt nok» - vi har gjerne kunnet leksene våre til minste detalj.

Jeg tror denne utvelgelsen av dukser til legeyrket har vært bra for norsk medisin (1). Norske leger har som gruppe vært både arbeidsomme og dyktige. Kvaliteten på legetjenestene har vært høy. Nylig gjestet jeg årsmøtet til Eldre lægers forening. Det er fascinerende å høre seniorene i norsk medisin fortelle om hvordan legeyrket har fylt deres liv. Innsatsen for pasientene og oppofrelsen i yrket går ofte igjen i fortellingene.

Det stilles krav i mange yrker, men i mitt fag kan omtrentligheter få store konsekvenser, sa nevrokirurgen Arild Egge i et intervju for en tid tilbake (2). Han var urolig for det han kalte industrialiseringen av yrket. Faget er i ferd med å trivialiseres, mente han. Men en god nevrokirurg kan ikke være en ni-til-fire-lege. Nevrokirurgi krever erfaring, entusiasme, hardt arbeid - bare dette kan føre til perfeksjon. Det er vel og bra med en uthvilt lege, men det vil ha sin pris ved at kirurgen får mindre erfaring. Dette underslås i diskusjonen, og det er å lure pasientene, sa Egge. Perfeksjonisme på alle plan er en forutsetning for et best mulig pasienttilbud. Evnen og viljen til å yte maksimalt og kreve det beste har fått et altfor negativt stempel, syntes han. Det blir fort snakk om elitisme i en slik sammenheng, noe det er lite rom for utenfor kultur- og idrettssektoren. Men å perfeksjonere seg i jobben bør ikke ha noen dårligere klang. «Jeg ser på perfeksjonisme som noe positivt og en nødvendig drivkraft. Tenk deg selv i rollen som pasient. Jeg er mye mer redd for konsekvensen av mangel på perfeksjonisme enn frykten for hva det kan føre til,» sa Egge (2).

Få dager senere fikk Egge svar (3). Christer Mjåset, en ung lege som arbeidet ved samme avdeling, sa til avisen at eldre leger har det med å forherlige dette med å jobbe mye. «Mange hadde jo selv hjemmeværende kone som tok seg av barn og hus da de var assistentleger. Men det er ikke bare antallet timer som betyr noe for å bli en dyktig lege. Hvordan man organiserer innholdet i timene er like viktig. Der har norske sykehus mye å lære. Det burde ikke være nødvendig å jobbe i fritida når man allerede går 19-timersvakter.
Man burde heller få ordentlig oppfølging de timene man faktisk er på jobb,» sa Mjåset (3). Både Egge og Mjåset har noen poenger. Men hvordan gi det best mulige pasienttilbud i en ny tid?

Av en eller annen grunn er perfeksjonisme blitt knyttet til kjønn. «Flink pike-syndromet» heter det. Kanskje er begrepet mer aktuelt enn det var før - nå som to tredeler av legestudentene er kvinner (4)? A lide av «flink pike-syndrom» er åpenbart ikke noe å trakte etter. Nei, hør her, jenter, sies det både direkte og indirekte helt fra barnehagen av, dere må bli mer som gutta. Hvis ikke kan dere bli utslitt og utbrent og møte veggen og få utmattelsessyndrom og bli liggende i mørke rom i kjelleren i årevis. Oops, best å slutte å være flink, gitt, og det litt brennkvikt (5).

Men hvordan ble det slik at høy plikt- og ansvarsfølelse og det at man stiller høye krav til seg selv ble noe negativt? I virkeligheten er det jo folk som mangler disse egenskapene som burde bekymre. Skrytepaver og svingkuttere er ikke noe å satse på (5). Alle personlige egenskaper har en oppside og en nedside. «Flink pike»-stempelet er gjennomsyret av nedsidene, påpeker journalist Eva Grinde i Dagens Næringsliv. Pliktfølelse blir til at du kun presterer for å blidgjøre andre, perfeksjonisme til at du er livredd for å gjøre feil, og ansvarsfølelse til at du er like forutsigbar og kjedelig som en pensumliste (5).

Alle tilbøyeligheter kan selvsagt løpe løpsk, og noen kan bli sykelig opptatt av å prestere hundre prosent på alle livets arenaer. Det kan hende at kvinner er mer utsatt. Men i arbeidslivet ønsker vi oss flinke folk. For ikke bare er dette prima egenskaper, de er helt nødvendige for alle som har lyst til å bli gode i noe, påpeker Grinde (5).

Folk som er flinke til noe, utmerker seg nemlig ikke først og fremst ved medfødt talent, men ved iherdig, nitid innsats. Da kommer «flink pike»-egenskaper som perfeksjonisme, iherdighet og pliktfølelse godt med. Og det er ingenting som tilsier at disse egenskapene kommer alene heller, slik man ofte kan få inntrykk av. «Flinke piker» kan gjerne være grensesprengende, modige, kreative og innovative (5). Vi bør ønske oss flinke piker av begge kjønn i legeyrket.

Litteratur

1. Hem E. Legepersonlighet - finnes det? Tidsskr Nor Legeforen 2013; 133: 2223 2. Halvorsen BE. Helt perfekt. A-magasinet 24.2.2012: 24-31.

. Sande GES. Legeforfatter ut mot Sykehus-Norge. Dagsavisen 27.2.2012: 20-1. www.dagsavisen.no/kultur/nye-boker/legeforfatter-ut-mot-sykehus-norge (16.11.2013)

4. 2013-2. Medisinstudenter i Norge og medlemmer av Nmf etter universitet og studieland og kiønn per 6.6. 2013. Den norske legeforening.

http://legeforeningen.no/Emner/Andre-emner/Legestatistikk/Medisinstudenter-/ Medisinstudenter-i-Norge-etter-kjonn-og-medlemmer-av-Nmf-i-Norge-ogutlandet-etter-kjonn/medisinstudenter-i-norge-og-medlemmer-av-nmf-etteruniversitet-og-studieland-og-kjonn-per-1004-201222/ (16.11.2013).

5. Grinde E. Ja til flinke piker! Dagens Næringsliv 16.5.2011. www.dn.no/karriere/ article2143239.ece (16.11.2013). 